\title{
The Role Of The Notary Deed Against Making Special Power Of Attorney To Say "Talaq" In Application Divorced In Religious Court
}

\author{
Dwi Indah Wahyuningsih ${ }^{1}$, Heni Agustiningsih ${ }^{2}$ and Achmad \\ Sulchan $^{3}$
}

\begin{abstract}
The purpose of this study were: 1 ) to identify and analyze the role of the notary to manufacture special power of attorney notarized deed oath in filing for divorce in the Religious Court. 2) To identify and analyze the constraints notary in the manufacture of a special power of attorney notarized deed oath in filing for divorce in the Religious Court. The data used in this study are primary data, secondary data, and the data to support the assessment tertiary then analyzed with normative juridical method. Based on the results of data analysis concluded that: 1) In the implementation of the signing of the deed notarized power of special oath divorce in filing for divorce in the Religious of the parties, giving the power of attorney privilege and receiving power of attorney privilege to be present and facing the notary as the deed notarized letter The special power, because the authorizing unable to attend the oath of divorce in the Religious; 2) The provisions of the terms to make a notarized certificate of the applicant should include both the giver and the recipient of a special power of attorney and shown directly to the notary who will make the notary deed so that certificates can be made in accordance with existing procedures.

Keywords: Notary; Special Power of Attorney; Notary Deed
\end{abstract}

\section{Introduction}

In this life, God created creatures in pairs, as man was created there were men and women of course there is a purpose to be taken in pairs is by entering into a marriage. Marriage in religious terms is called "nikah" (Arabic: Lang.) means: aqad or agreement to bind between a man and a woman to justify the sexual contact between the both sides to realize the happiness of family life that overwhelmed with compassion and peace by means blessed by the God.

Regarding the notion of marriage is a lot of some of the opinions that differ from one another. But this disagreement is actually not to show genuine disagreement between the opinions with each other. Differences are only found in the desire of the formulator to incorporate elements as much as possible in the formulation of the notion of marriage on the one hand and limiting the number of elements in the formulation of the notion of marriage on the other. They limit the number of elements included in the formulation of the definition of marriage, will describe other elements in the purpose of marriage. $^{4}$

Marriage Act, in section 1 formulate the notion of marriage as follows: "Marriage is a bond inner and outer advance of one man and one woman as husband and wife with

\footnotetext{
${ }^{1}$ Students of Master of Notary Law Faculty of Law Students of Master of Law, Faculty of Law, Universitas Islam Sultan Agung email: dwiindahwahyunigsih137@gmail.com

2 Students of Master of Law, Faculty of Law, Universitas Islam Sultan Agung email agustinheni50@gmail.com

${ }^{3}$ Lecturer in Faculty of Law UNISSULA Semarang

${ }^{4}$ Ny.Soemiyati Hukum Perkawinan Islam Dan Undang-Undang Perkawinan (Undang-undang No

1 Tahun 1974 Tentang Perkawinan) Yogyakarta Liberty 2007.
} 
the aim of forming a family (household) who are happy and everlasting based on God".

If we compare the formulation according to Islamic law above the formulation in article 1 of the Marriage Law of the meaning of marriage is no difference of principle.

Judging from the legal aspect of marriage is an agreement divulging. Word of Allah: "How would you take it back, in case some of you have been associated with another as husband and wife, and they (wives) have taken from you a strong pledge" (Qur'an, An.Nisaa ': 21)

Agreement in this marriage has / contains three special characters, namely:

- Marriage can not be done without the voluntary element from both sides.

- Both sides (men and women) binding mutual consent the marriage has the right to terminate the agreement was based on the provisions of existing laws.

- Approval marriage was set legal boundaries on the rights and obligations of each party.

If a woman and a man said, agreed to a marriage with each other means they each promised to obey the rules of law in force concerning the obligations and rights of each party during and after living together was taking place, and the position in society of children offspring. Also in stopping the marriage, the husband and wife are not fully free to decide for themselves the conditions for the termination, but also tied to the legal regulations concerning it.

Article 1 of Act No. 1 of 1974 on Marriage provides a definition that marriage is inner and outer bond between a man and a woman as husband and wife with the aim of forming a family (happy family) and eternal based on God.

According to Article 1 of Act No. 1 of 1974 on Marriage formulate, that the husbandwife bond is based on God, marriage is a sacred engagement. Engagement can not let go of the religious affiliation of husband and wife. Living with a husband and wife in marriage is not solely for the smooth conduct of sexual intercourse remained at the couple but can form a happy home, household harmonious, secure and harmony between husband and wife. The marriage of one sacred covenant between a man with a woman to form a happy family. ${ }^{5}$

If the views of Islamic law, Understanding (ta'rif) marriages under Article 1 Compilation of Islamic Law is marriage, namely: aqad very strong or mitsaaqaan ghaaliizhan to obey the commands of Allah, and to implement the worship. Doing acts of worship means following religious teachings. The marriage of one legal actions that may be undertaken by a qualified mukallaf.

Whoever marries means he has carried out half again, let him piety to Allah SWT. Thus sunnahqauliyah (sunnah in the form of words) Rasullullah Saw.

Although basically do a marriage that is aiming for ever, but sometimes there are specific causes that lead to marriage can not be continued so should be decided in the middle of the road or for attrition by itself, or in other words the divorce conduction husband and wife.

Figh experts divorce in terms of so-called "divorce" or "furqah". As for the meaning of divorce is: untie cancel the agreement. While "Furqah" means a divorce, which is opposed to the gathering. Then the two words used by experts figh as one term, which means: divorce between husband and wife. Words divorce in figh term has two meanings, that is common sense and a very specific meaning.

Divorces according to the general sense is that all forms of divorce imposed by the husband, which is set by the judge, nor the divorces fell by itself or divorce because of

\footnotetext{
${ }^{5}$ Rosnidar Sembiring Hukum Keluarga Harta-Harta Benda dalam Perkawinan
} 
the death of one of the spouses. Divorces in particular means that divorce is imposed by the husband. Because one form of divorce between spouses exists due to divorce then for the next term divorce here meant as a divorce in a special sense. ${ }^{6}$

The above has been explained that the purpose of marriage than that commanded by Islam is marriage intended to everlasting on the basis of mutual love between husband and wife. Marriages performed deviating from the prescribed purpose, is haraam. For example, a marriage that aim only for a short while or just to let go of lust alone (temporary marriages), muhallil marriage and others.

In carrying out the life of a married of course not always be in a situation that is peaceful and serene but sometimes it happens also misunderstanding between husband and wife or one of the parties dereliction of duty, not believing-trusting each other and others.

In the circumstances of this tension arises, it can sometimes be overcome so that between the two became good again, but sometimes it becomes protracted ideology error, can not be reconciled and constantly quarrel between husband and wife that. If divulging such marriages that followed the establishment of a peaceful household and serene as prescribed by religion are not achieved. And also fear discord between husband and wife will lead to a split between the families of both parties. Therefore to avoid the breakdown of the family were more widespread, then Islam requires divorce as a way out of the last for a husband and wife who have been unsuccessful in fostering household.

Although Islam allow divorce does not mean that Islam like the dissolution of a marriage. And divorce also should not be carried out any time you want.

Although divorce is allowed but Islam remains the view that divorce is something that is contrary to the principles of Islamic law. This can be seen in the Hadiths of the Prophet, Messenger of Allah said:

"The kosher most hated God is Divorce". (Abu Dawud and expressed Shaheh by AlHakim)

For people who do divorce without reason, the Prophet said: "What caused the one you're with the law of God, he said: I actually have talaq (wife) and indeed I have already referred to (her)". (Reported by Ibn an-Nasaai and Hubban).

By looking at the contents of both the hadith mentioned above, it can be deduced that the divorce that although permitted by religion, but its implementation should be based on divulging the reason for the strong and the latter path taken by the husband and wife, eventhough divorce is a lawful act, but by God's wrath.

\section{Research methods}

The method used in this research is a normative juridical approach is to use secondary data as a primary source, and if there is a data field, the data is no more merely a supporting data for secondary data. While the views of his own research is descriptive analysis.

Through such study is expected to obtain a comprehensive overview, the legal protection of the public in making notarial deed notarized power of attorney deed particularly special oath in filing for divorce in religious courts.

\section{Results and Discussion}

\footnotetext{
${ }^{6}$ Ny. Soemiyati Op.cit
} 


\subsection{Role Against Notary deed notarized Power of Attorney Making Outstanding Pledge To Say Divorced "Talaq" In a Submission in Religious Court}

\subsubsection{Certificate Signing Procedure Notarized By Attorney Outstanding Pledge To Say Divorced "Talaq" In A Submission In Religious Court}

The procedure of signing a power of attorney specifically due to the special nature of the authorizing interests in say oath or pledge to be performed by an authorized and should form an authentic deed made before a competent authority, ie the notary.

The emergence of a special power of attorney preceded their divorce petition filed to make mediation before decided to divorce that was decided by the Religious Court and has had permanent legal force. Later Islamic Court summoned the ex-husband to arrive at the Religious Court hearing the oath of divorce to his ex-wife. Caused absent then it can authorize another person, where the power required to be a special power of attorney due to a special proxy will be the oath of divorce to his ex-wife authorizer. ${ }^{7}$ In Article 16 paragraph (1) letter 1 can be seen that before signed by the applicant, witnesses and a notary must be read first. This reading is done well against the deed of the party (Partij acte) or the official deed (acte amtelijke).

In Article 16 paragraph (1) sub-paragraph 1 of Notary Law mention "in running the office, notary is obliged to read the deed before applicant in the presence of at least two (2) witnesses and signed on the spot by applicant, witnesses and Notary.

The first sentence of Article 16 (1) of Notary Law show unequivocally who read the deed to the parties and witnesses. Notaries have an obligation to read the deed. The reading of the deed itself is one of the sate obligation for notaries to be carried out during a deed authentic. Without doing the reading of the deed in the presence of the parties and witnesses, it will lose its authenticity certificate. The readings are part of verlijden. The reading of the deed by notary guaranteeing the applicant that they sign the deed is a deed equally heard. Thus the notary and the applicant belief that the contents of the deed actually correspond to what was intended by the parties. The readings for the fulfillment of the formalities prescribed the legislation ${ }^{8}$.

During the reading of the deed held by the notary to the applicant and witnesses, the applicant given a chance to make a change or addition of the contents of the deed. The desire or the will of the applicant it can be directly submitted to the notary.

Changes or additions to the contents of the deed (renvool) is done at the discretion of the applicant. Every renvooi contained in the deed must be given the initials, by the applicant signed the deed. Initials Award is intended as an endorsement of any changes or additions required by the applicant. Renvooi means appointment to record in the deed of additional, and replacement legalized graffity. ${ }^{9}$

The reading of the deed is done by using a language that can be understood by the applicant. If applicant can not understand the language used by the notary deed readings can be carried out at the closure of the deed.

After, readings done by a notary deed in the presence of the applicant, witnesses and a notary. What is meant by the witness is a witness instumenter not witness which, as mentioned in Article 40 paragraph (3) of Notary Law, namely the identification of witnesses. The witness does not have a signature identifier but if the witness also gave

7 G.H.S. Lumban Tobing Peraturan Jabatan Notaris (Notaris Reglement) Penerbit Erlangga Jakarta 1999 p. 202.

${ }^{8}$ GHS Lumban Tobing Op. Cit p. 202.

${ }^{9}$ R. Soegondo Notodisoerjo Pengantar Hukum Notaris di Indonesia PT. Persada Raja Grafindo Jakarta 1993 p. 55-56 
a signature identifier in deed, then for that matter there is no objection by the legislation. Provision of signature by witnesses identifier does not affect the authenticity of the certificate.

Implementation of the signing of the deed must be preceded by the reading of the deed. This means that the signing of a deed executed after reading of the deed by the notary. If applicant signed the act of reading the signs to him to do the deed be losing sight of its authenticity.

The signing of the deed is proof that the deed was binding for the parties so that the signing is an absolute requirement to bind the deed. Affixing a signature is one of a series of inauguration of the deed (verlijden). Giving signature at the bottom of the deed is done, the part of the paper is still blank. Affixing a signature on the deed must be explicitly stated in the deed, this statement is given at the end of the deed as defined by subsection 44 (1) of Notary Law.

Affixing a signature in a deed containing the sense of providing information and statements in writing, which is what is written above the signature. ${ }^{10}$ It also confirms that the certificate actually signed by the applicant, witnesses and notary itself. Thus the witnesses who signed the deed can testify, that the formalities prescribed by law both on the reading and signing have been met. The order of the signing is done start and the applicant, followed by witnesses and most recently was a notary.

In case of applicant, if they can not or is unable to sign his name on the deed, the statement of reasons or are otherwise expressly by notary deed. If applicant not be able to sign his name because it can not read or write it applicant concerned can give a thumbprint. Thumbprint instead of a signature but a sign. Giving a thumbs it must be stated also in deed. We call it an authentic deed or agreement between two sides.

At the close of testimony given by a notary deed regarding the time and place of the deed created, followed by the testimony of witnesses and in the presence of who created and last deed on the reading and signing of the deed.

In accordance with the provisions of the legislation, namely Act No. 7 of 1989 on the Religious Courts Article 70 paragraph 4, which reads: (4) In the trial of the husband or his representative was given special powers in divulging deed authentic oath: divorce, which was attended by the wife or power. Based on research in the field, gained a clear picture of the state of the respondents. Next will be described the actions taken by the notary when there is a special power of attorney recipients who can not be present at the time of signing the deed. Statement of the respondents, for the first time all of them claim that if the parties can not come at the time of signing, the signing of the deed postponed. The delay is performed until the parties have got a deal on time for the signing. In this case the respondent does not limit how long the period of delay signing to be performed by the parties or to be forwarded by one of the sate party to the agreement. This is because the type of deed made is the deed of the parties (Partij acta), all matters relating to existing agreements submitted to the parties to make an agreement.

The word comes from the word delay delay by Indonesian dictionary means stop and will hold the time (another time), suspend, postpone. From the meaning given the delay in signing the deed means to suspend execution of the deed signed by the parties to delay the initiative of a notary.

Be followed one after another comes from the word meaning came later, follow or pursue something in the future, thus meaning given by Indonesian dictionary.

${ }^{10}$ R. Soegondo Notodisoerjo Op. Cit. P. 210. 
Forwarding of the deed signature by the parties interpreted one of the parties signed the act at a later time after the other party signed in advance.

Existing agreement between the parties to a treaty is one of the requirements the validity of the agreement as set forth in Article 1320 Book of the Law, Civil Law. The agreement is deemed to have been reached if the parties mutually accept what they want. The statement will set forth in the deed is a form of a written statement has been the agreement. Implementation of the signing is proof has been achieved agreement between the parties.

Up to now there is no strict regulation of how the difference in time for the parties to sign the deed before a notary. The signing of the deed of determining whether or not binding on the contents of the agreement. If the deed is only one of the parties who signed it can not be said to have been no agreement between the parties. Article 1338 Book of Civil Law states that appear agreement binding them as legislation. With the signing of the deed made by the parties before a notary that the deed be binding on the parties to the agreement. A deed made before a notary will provide the perfect proof for the parties if the deed inauguration procedure in accordance with what is prescribed by law. Under Article 165 HIR an authentic deed is a perfect evidence for the parties, their heirs and those who have the right of him. Perfect in the sense that with the authentic deed we do not need other evidence. When the deed inauguration procedure was not carried out as specified by the legislation then deed it becomes deed under hand.

\subsubsection{The Authenticity Of The Special Power Of Attorney In Notary Deed}

Value authentic a notary deed not be met regardless of whether or not a procedure. specified in the regulations that govern which in this case is Regulation Notary. A certificate can be said to be authentic if it meets:

- Notarial deed is a deed made by in the presence of the authorities to it;

- There is no certainty the date thereof;

- There is a certainty about who signed. signed by the individual himself;

- Notary had advised before the deed was made, which are prohibited and which are not:

- If there's no denying the truth of the deed, then deny it to be proved. which indisputably do not have to prove anything;

- The notarial deed must be kept confidential by a notary. ${ }^{11}$

Of Article 44 paragraph (1) of Notary Law be clear that any notary deed before the signing must first be read out a whole to the applicant and witnesses, both deed party (Partij acte) and certificate authorities (ambtelijke acte), This reading is part of the socalled verlijden (reading and signing) from the deed. ${ }^{12}$

Readings remain to be done by a notary deed to the applicant at the same time. This reading is intended to applicant know the contents of the deed and get an explanation of the deed to be signed. When will be changes and / or additions by the applicant can be submitted at the time of reading. The benefits of reading the deed is:

- At the last moment in the process of formalizing (verlijden) deed, notary still given a chance to correct their own mistakes not previously seen;

- The applicant given the opportunity to ask what is less obvious to them;

\footnotetext{
${ }^{11}$ A. Kohar Lawyer in Legal Practice (City: Publisher Alumni 1983) p. 31.

${ }^{12}$ A. Kohar Op. Cit. p. 31.
} 
- To give a chance to the notary and the applicant in the last seconds before the deed was completed inaugurated with their signatures, the witnesses and the notary, held rethinking, questioning and if necessary change the sound of the deed. ${ }^{13}$

\subsection{Notary Obstacles In Making Power of Attorney Outstanding Pledge To Say Divorced "Talaq" In a submission in Religious Court}

After doing some research at the notary office of Sri Wahyuningsih $\mathrm{SH}, \mathrm{MKn}$ at $\mathrm{Jl}$. Kingdom Sayung-Demak Km 8.5, the authors found these constraints derived from the applicant's own notarized deed. The following constraints that I have found during fieldwork:

- Authorizing special as applicant could not attend.

Constraints party authorizer can not be present in the implementation of the process of signing the deed notarized power of attorney privilege in the oath of divorce in the filing for divorce in the Religious because the donor power of attorney privilege is outside relation to the work being carried out so as not facing a notary will make a notarized deed.

- Special endorsee as applicant could not attend.

Constraints receiver special power of attorney can not be present in the process of signing the deed notarized letter special goad the oath of divorce in the Religious because the recipient was absent special power of attorney so could not face the notary who will make the notary deed.

- Terms of the incomplete

Constraint conditions are less complete in this case the applicant both the giver a power of attorney privilege and receiving power of attorney privilege is sometimes not complete the document as a supplement to the requirements in a deed notarized at the notary's office such as identification or ID cards because of missing yet ID cards new replacement so that the process deed notarized special power of attorney can not be processed.

- Physical disability right thumb fingerprint.

- Fingerprint associated with the right thumb has become one of the requirements for completeness so that no falsification of signatures which become obstacles when applicant not have the right thumb as a result of certain events (disability).

- Damage documentation.

- Related to this documentation menjdi one visual evidence anyone SJA overlooking the notary who signed the obstacles that arise usually unnoticed or cctv camera could not function because of the damage occurred.

\section{Closing}

\subsection{Conclusion}

Based on the issues that have been pointed out above, and by analysis Data obtained from the results of field research, it can take the conclusion:

- Based on the findings in the field, the role of the notary in the implementation of the signing of the deed notarized power of attorney privilege in the oath of divorce

13 Tan Thong Kie Study Notarist \& Paraphernalia notary practice PT. Buana New Van Hoeve Jakarta 2000 p. 224. 
in the filing for divorce in the Religious of the parties, giving the power of attorney privilege and receiving power of attorney privilege should present itself and facing a notary public as the creator of notary deed the special power of attorney.

- Related terms less complete the applicant both the giver a power of attorney privilege and receiving power of attorney privilege must complete the first and on the show before a notary that notary deed can be made, and also at the notary's office frequently to check regularly on the completeness of the office mainly documentation.

\subsection{Suggestion}

Based on the description contained in the discussion, the suggestions as follows:

- Implementation of the signing of the deed notarized special power of attorney in the oath of divorce in the filing for divorce in the divorce courts that were made by notaries can be accomplished with either side facing the endorser endorsee special or privileged in the presence of a notary.

- Before the signing of the deed notarized power of attorney privilege in the oath of divorce in the filing for divorce in the Religious is expected to first conduct an audit on the completeness of the terms that the need for the giver and the receiver the power of attorney privilege to make the notary deed and also the notary's office often conduct periodic checks related to the completeness of documentation, especially office (CCTV).

\section{Bibliography}

[1] Kohar, Lawyer in Legal Practice (City: Publisher Alumni, 1983).

[2] Rosnidar Sembiring Hukum Keluarga Harta-Harta Benda dalam Perkawinan Raja Grafindo Persada 2016

[3] G.H.S. Lumban Tobing Peraturan Jabatan Notaris (Notaris Reglement) Penerbit Erlangga Jakarta 1999.

[4] Ny.Soemiyati Hukum Perkawinan Islam Dan Undang-Undang Perkawinan (Undangundang No 1 Tahun 1974 Tentang Perkawinan) Yogyakarta Liberty 2007.

[5] R. Soegondo Notodisoerjo Pengantar Hukum Notaris di Indonesia PT. Persada Raja Grafindo Jakarta 1993.

[6] Tan Thong Kie Study Notarist \& Paraphernalia Notary Practice PT. Buana New Van Hoeve Jakarta 2000.

[7] Tim Penyusun Kamus Pusat Pembinaan dan Pengembangan Bahasa Kamus Besar Bahasa Indonesia Penerbit Balai Pustaka Cet. ke-3 Jakarta 1990.

[8] Indonesia the Constitution of 1945

[9] Indonesia the Legal Department and Deputy Vice notary notary Meanwhile Act No. 33 of 1954 LN No. 101 of 2004 . TLN 700 S.2. 